\title{
Integrated management of treated wastewater reuse in irrigation and its role in environment conservation
}

\author{
A. A. Al-Othman ${ }^{1} \&$ M. M. Selim ${ }^{2}$ \\ ${ }^{1}$ Department of Agricultural Engineering, \\ College of Food and Agricultural Sciences, \\ King Saud University, Saudi Arabia \\ ${ }^{2}$ Field Crop Research Department, National Research Centre, \\ Cairo, Egypt
}

\begin{abstract}
Availability of suitable water is considered one of the most important factors in increasing and expanding cultivated areas. In arid and semi-arid areas where water is scarce, several studies and researches have indicated the beneficial role of reusing wastewater in partially solving this problem. Moreover, the reuse of wastewater helps in protecting the environment as it reduces pollution and causes no harm to plants, groundwater and human health. Therefore, the main objective of this study is to pin point the economic benefits of reusing secondary treated wastewater, which begins by separating solid materials from liquid and then activating living microorganisms as a means of making the best use of the existing resources.

In this study, field surveys were made for summer and winter crops throughout three seasons in rotation to evaluate the impact of irrigation with secondary treated wastewater on the yield and quality of some field crops in comparison to canal water. In each season, treatments included using two sources of irrigation water; i.e. wastewater and canal water, and two fertilization treatments (application recommended rates of chemical fertilizers and control). Crop selection included fodder, oil crop, sugar crop and grain crops. Results demonstrated that crops irrigated with secondary treated wastewater were equally similar to or significantly better than those irrigated with canal water. Heavy metal concentrations were very low and had no effect on the crop quality or animal and human dietary intake. There were no detectable effects of
\end{abstract}


wastewater on soil quality. Results also indicated that wastewater could offer an adequate amount of crop requirements from $\mathrm{N}$ and more crop requirements of $\mathrm{K}$. Keywords: reuse treated wastewater, irrigation, environment conservation.

\section{Introduction}

The current water budget in Egypt shows that the annual water demand exceeds the available of fresh water by 6 billion $\mathrm{m}^{3} /$ year [1]. Water uses are rising due to the ambitious land reclamation programme, a growing population, steady rural development and urbanization plans, and expanding the industrial sector. Therefore, it is essential to develop water resources through untraditional ways.

During recent years the methodology of reuse wastewater management has shifted from conventional disposal strategies into value added products [2]. Literature indicates that recycle wastewater effluent has a number of advantages, including the improvement of soil physical conditions and fertility [3]. Therefore, wastewater has been used to support the agricultural production in many countries such as USA, Germany, India, Kuwait, Saudi Arabia, Oman, Jordan and Tunisia [4]. The area of irrigated land with wastewater increased significantly over two past decades due to constrains on water supply and increasing the concerns over the environmental implications [5].

In Egypt, the plan for reuse municipal wastewater for irrigation is not new, but it has been practiced since 1911 on the sandy soil of EL-Gabal EL-Asfar farm, which consists of an area of 1200 ha, $25 \mathrm{Km}$ North East of Cairo, it has been irrigated by wastewater from Cairo treatment plants and is producing citrus, date palm and pecan nuts in addition some field crops.

Several investigators indicated the beneficial role of wastewater in increasing crop yields without or with minimal risks to the plant, soil, groundwater and human health [6-11]. Therefore, the aim of this work is to evaluate the effect of treated wastewater on crop yield and quality under calcareous sandy soil of Egyptian conditions.

\section{Materials and methods}

Large scale field trials were carried out over three years of experiments in a rotation of summer and winter seasons. The main objective of this study is to manipulate the effects of using secondary treated wastewater compared with canal water in the presence or without application of recommended dose of chemical fertilizers. An additional target is to offer a model for environmental improvement by opening new usage of treated wastewater in agriculture and consequently reduction of pollution load. The experimental soil was sandy loam in texture (45\% sand, $35 \%$ silt and $20 \%$ clay) with high $\mathrm{CaCO}_{3}(34.62 \%)$. Chemical analyses of the soil experiment were presented in tables 1 and 2 . Samples of treated wastewater were taken during crop season and analyzed and recorded in table 3. Crop selection included a range of fodder and grain crops according to [12], crops which were not intended to be eaten raw. 
The present studies will discuss the results of yield and quality of lentil and pearl millet. The experiments were irrigated by flood irrigation systems and an applied quantity was measured by calculating the number of tanker used over the growth period according to crop water requirements as observed in the field and when reached to water field capacity. The quantities of water are nearly equal in both sources of irrigation and are broadly in line with normal practice.

Table 1: Chemical properties of the soil sites.

\begin{tabular}{|c|c|c|c|c|c|c|c|c|c|c|c|c|}
\hline \multirow{2}{*}{ Depth } & \multirow{2}{*}{ SP } & \multirow{2}{*}{$\mathrm{pH}$} & \multirow{2}{*}{$\mathrm{ECdS} / \mathrm{m}$} & \multicolumn{4}{|c|}{ Soluble Cat ions $(\mathrm{meg} / \mathrm{L})$} & \multicolumn{4}{|c|}{ Soluble Anions (meg/L) } & \multirow{2}{*}{$\begin{array}{c}\mathrm{CaCO}_{3} \\
\%\end{array}$} \\
\hline & & & & $\mathrm{Ca}^{++}$ & $\mathrm{Mg}^{++}$ & $\mathrm{Na}^{+}$ & $\mathrm{K}^{+}$ & $\mathrm{CO}_{3}=$ & $\mathrm{HCO}_{3}^{-}$ & $\mathrm{Cl}^{-}$ & $\mathrm{SO}_{4}{ }^{=}$ & \\
\hline $0-25$ & 53.3 & 8.30 & 4.34 & 11.1 & 7.9 & 22.4 & 2.0 & 0 & 1.2 & 23.5 & 18.7 & 28.46 \\
\hline $25-70$ & 48.3 & 8.20 & 3.63 & 10.5 & 7.2 & 16.9 & 1.7 & 0 & 1.0 & 22.9 & 12.4 & 30.77 \\
\hline $70-120$ & 50.0 & 8.17 & 2.50 & 8.1 & 6.0 & 9.7 & 1.2 & 0 & 0.9 & 14.3 & 9.8 & 34.62 \\
\hline
\end{tabular}

pH: in soil: water 1:2.5 suspension, EC: in soil paste extract.

Table 2: $\quad$ Available nutrients of the experimental soil site.

\begin{tabular}{|c|c|c|c|c|c|c|}
\hline \multirow{2}{*}{ Depth } & \multirow{2}{*}{ Total Nppm } & \multicolumn{4}{|c|}{ Available nutrients ppm } & \multirow{2}{*}{ O.M \% } \\
\cline { 3 - 5 } & & $\mathrm{P}$ & $\mathrm{Fe}$ & $\mathrm{M}$ & $\mathrm{Zn}$ & \\
\hline $0-25$ & 4.17 & 2.5 & 3.1 & 3.9 & 1.5 & 1.7 \\
\hline
\end{tabular}

Table 3: $\quad$ Chemical composition of treated wastewater used.

\begin{tabular}{|c|c|c|c|c|c|}
\hline $\mathrm{pH}$ & $\mathrm{EC} \mathrm{dSm}^{-1}$ & & \multicolumn{2}{|l|}{ SAR } & \\
\hline 7.8 & 3.10 & & 9.30 & & \\
\hline \multicolumn{6}{|c|}{ Soluble cations (meq/l) } \\
\hline $\mathrm{Ca}^{++}$ & \multicolumn{2}{|c|}{\begin{tabular}{l|l}
$\mathrm{Mg}^{++}$ & \\
\end{tabular}} & \multicolumn{2}{|l|}{$\mathrm{Na}^{+}$} & $\mathrm{K}^{+}$ \\
\hline 5.8 & 3.2 & & 19.8 & & 2.2 \\
\hline \multicolumn{6}{|c|}{ Soluble anaions (meq/l) } \\
\hline $\mathrm{CO}_{3}{ }^{=}$ & $\mathrm{HCO}_{3}^{-}$ & & \multicolumn{2}{|l|}{$\mathrm{Cl}^{-}$} & $\mathrm{SO}_{4}{ }^{2}$ \\
\hline 1.1 & 6.6 & & 18.2 & & 5.2 \\
\hline \multicolumn{6}{|c|}{ Nutrient $(\mathrm{meq} / \mathrm{l})$} \\
\hline $\mathrm{NH}_{4}$ & $\mathrm{NO}_{3}$ & $\mathrm{P}$ & $\mathrm{Mn}$ & $\mathrm{Cu}$ & $\mathrm{Zn}$ \\
\hline 0.23 & 2.19 & 9.50 & 0.20 & 1.10 & 0.80 \\
\hline
\end{tabular}

SAR: sodium absorption ratio.

Nitrogen, phosphorus and potassium fertilizers were applied as ammonium nitrate $(33.5 \% \mathrm{~N})$, calcium super phosphate $\left(15.5 \% \mathrm{P}_{2} \mathrm{O}_{5}\right)$ and potassium sulphate $\left(48 \% \mathrm{~K}_{2} \mathrm{O}\right)$, respectively according to the normal recommended rates in Egypt.

The experimental design was a split-plot design in four replications. Water source was in the main plot and fertilization treatments were assigned randomly in sub-plots. Each experiment included 4 treatments: 2 water resource (secondary treated wastewater, canal water) and 2 fertilization treatments \{control (without 
application) and application recommended dose of NPK\}. The experimental area was ploughed twice ridged and divided to experimental unites $21 \mathrm{~m}^{2}$ each. Sowing dates took place in the recommended date of sowing for each crop. All agronomic practices were followed as recommended.

At harvest time, two inner rows for each crop were randomly pulled from each plot for determined seed yield $\mathrm{Kg}$ per plot as well as biological yield and then calculated per faddan. A sub sample of ten plants was taken for determining yield component characters i.e., number of pods/plant and 1000 seed weight in grams. Seed qualities in absolutely dry seeds for each crop were also determined according to the methods described by [13], samples of seeds were taken randomly from each plot and mixed to create a representative sample, then divided it to two replicates. Micronutrients and heavy metals were determined in dry ash digestion according to the literature procedure [14].

The obtained data for each crop as well as each season were statically analyzed by analysis of variance [15]. The trend of the three seasons were nearly similar. Then uniformity test was done and combined analyses for the three seasons were calculated Means of the treatment were compared by the new least significant difference.

\section{Monitoring wastewater quality}

Samples of treated wastewater were taken during crop cycles and analyzed according to the literature procedure [16], for a range of agronomic, environmental and health parameters. Nutrient and heavy metal loading rates to field trials were calculated according to the irrigation quantities applied to each crop in order to assess the acceptability of these wastewaters for reuse in short and long-term of full-scale operation of the wastewater treatment plants. Another objective of these analyses was to determine wastewater compliance with the Egyptian limit values Degree 44/2000.

\section{Results and discussion}

\subsection{Effect on seed yield, yield component characters as well as seed quality of lentil:}

Data presented in table 4, clearly emphasized the response of lentil to irrigation with secondary treated wastewater grown under low fertile calcareous sandy soil. Irrigation with treated wastewater increased the seed yield of lentil by 8.83 over the irrigation with canal water. Such increase in seed yield due to irrigation with treated wastewater could be attributed to the nutrient content in wastewater which can offer a part of the crop requirement from $\mathrm{N}$, all of $\mathrm{P}$ and $\mathrm{K}$. The obtained data support that reported by $[5,11]$. In this respect, the application of $25 \mathrm{~mm}$ wastewater was enough to supply $40-80 \%$ of corn requirement from $\mathrm{N}$ and all of requirement from $\mathrm{P}$ [4]. The available data of other researchers pointed out that the increased in yield as the result of irrigation with wastewater may be due to the enhancement of nutrient up take and the improvement of the 
hydrophysical properties of soil. Regarding to, application of the recommended dose of chemical fertilizers, data in table 4 indicated that seed yield obtained from plots irrigated solely with treated wastewater surpassed that irrigated with canal water in the presence of chemical fertilizers. Results also clearly confirmed that additional fertilizers to plants are necessary to achieve economic yield under such conditions. In addition to the data presented in table 4, it also shows that no statistical differences between either water sources or application of the recommended dose of chemical fertilizers as well as their interactions on seed content of fatty acid, crude protein and carbohydrate. This means that plots irrigated with treated wastewater alone or in the presence of $\mathrm{N}, \mathrm{P}$, and $\mathrm{K}$ fertilizers are equal with those irrigated with canal water.

Table 4: $\quad$ Yield and yield component characters as well as seed quality of lentil seeds as affected by irrigation with different water resources, fertilization treatments and their interactions. (Average of three seasons.)

\begin{tabular}{|c|c|c|c|c|c|c|c|c|}
\hline Irrigation & $\begin{array}{c}\text { Fertilization } \\
\text { Treatment }\end{array}$ & $\begin{array}{l}\text { No. of } \\
\text { pods/ } \\
\text { plant }\end{array}$ & $\begin{array}{l}1000 \text { seed } \\
\text { weight }(\mathrm{g})\end{array}$ & $\begin{array}{c}\text { Biolog.; } \\
\text { yield, } \\
\text { Kg/fad. }\end{array}$ & $\begin{array}{l}\text { Seed yield } \\
\text { /faddan, } \\
(\mathrm{kg})\end{array}$ & $\begin{array}{c}\text { Fatty acid } \\
\mathrm{g} / 100 \mathrm{~g}\end{array}$ & $\mid \begin{array}{c}\text { Crude } \\
\text { protein } \%\end{array}$ & $\begin{array}{c}\text { Carbohydrates } \\
\%\end{array}$ \\
\hline \multirow{3}{*}{ Wastewater } & Control & 22.9 & 28.5 & 3967.6 & 544.2 & 2.0 & 24.4 & 60.4 \\
\hline & $\begin{array}{l}\text { Recommended } \\
\text { Dose of NPK }\end{array}$ & 24.6 & 28.9 & 4844.3 & 655.8 & 2.2 & 24.5 & 60.8 \\
\hline & General Mean & 23.8 & 28.7 & 4405.9 & 600.0 & 2.1 & 24.5 & 60.6 \\
\hline \multirow{3}{*}{ Canal water } & Control & 20.7 & 28.2 & 3684.7 & 456.9 & 1.9 & 23.9 & 60.4 \\
\hline & $\begin{array}{l}\text { Recommended } \\
\text { Dose of NPK }\end{array}$ & 23.7 & 28.9 & 4851.0 & 645.6 & 2.4 & 24.2 & 60.8 \\
\hline & General Mean & 22.2 & 28.6 & 4267.8 & 551.3 & 2.2 & 24.1 & 60.6 \\
\hline \multirow{3}{*}{$\operatorname{LSD} 5 \%$} & Irrigation (A) & 1.0 & n.s & 44.8 & 20.8 & n.s & n.s & n.s \\
\hline & Fertilization T.(B) & 2.2 & n.s & 134.7 & 34.2 & n.s & n.s & n.s \\
\hline & Interaction $\mathrm{AxB}$ & 1.6 & n.s & 89.5 & 30.5 & n.s & n.s & n.s \\
\hline
\end{tabular}

Concerning the concentration of heavy metals in seeds, data presented in table 5, makes it clearly obvious that no consistent effects were detected on concentrations of heavy metal in seeds resulting from irrigation with treated wastewater compared with canal water. Although, secondary treated wastewater removed up to $90 \%$ of heavy metals into the sludge, the wastewater resulting after treatment contained a wide range of contaminants reflecting in its quality. According to the data recorded, the ranges of concentration are within normal

Table 5: Mean concentration of heavy metals in lentil seeds grown in calcareous soil as affected by water quality. (Average of three seasons.)

\begin{tabular}{|c|c|c|c|c|c|c|}
\hline Irrigation & $\mathrm{Zn}$ & $\mathrm{Cu}$ & $\mathrm{Cr}$ & $\mathrm{Cd}$ & $\mathrm{PB}$ & $\mathrm{Ni}$ \\
\hline Wastewater & 33.6 & 3.92 & 0.25 & 0.024 & 0.75 & 0.22 \\
\hline Canal water & 28.8 & 3.19 & 0.17 & 0.022 & 0.36 & 0.18 \\
\hline
\end{tabular}


ranges, and are for below levels that would be of concern. In addition to zinc and copper are essential trace elements, which are often deficient in Egyptian crops due to the high $\mathrm{pH}$, especially in calcareous soil. This statement is suggested by the deficiency for zinc and likely cooper that were seen in a number of crops in different locations.

\subsection{Effect on fresh, dry and forage quality of pearl millet:}

Results obtained in table 6 revealed that irrigation with treated wastewater increased fresh and dry weight of the forage yield in the $1^{\text {st }}$ an $2^{\text {nd }}$ cut as well as the main cut of millet. Increment was 8.84 and $9.19 \%$ in total fresh and dry weight of first and second cut, respectively. The increment in the main cut was 2.69 and 11.62 in the fresh and dry weight of millet. In general the forage yield of main cut was higher than the total of two cuts; this is may be due to the long term of growth for the main cut. Application of chemical fertilizers to both water irrigation resources led to an increase in forage yield. Such increment clearly confirmed that additional fertilizers to plants, especially under low fertile soils, are necessary to achieve economic levels. Present data are suggested by the data reported in the literature $[17,18]$.

Table 6: Fresh and dry forage of pearl millet ton/faddan as affected by irrigation with wastewater, fertilization treatments and their interactions (Average of three seasons).

\begin{tabular}{|c|c|c|c|c|c|c|c|c|c|}
\hline \multirow{2}{*}{$\begin{array}{l}\text { Irriga- } \\
\text { tion }\end{array}$} & \multirow{2}{*}{$\begin{array}{c}\text { Fertilization } \\
\text { Treatment }\end{array}$} & \multicolumn{2}{|c|}{$1^{\text {st }}$ cut } & \multicolumn{2}{|c|}{$2^{\text {nd }}$ cut } & \multicolumn{2}{|c|}{ Total } & \multicolumn{2}{|c|}{ Main cut } \\
\hline & & Fresh & Dry & Fresh & Dry & Fresh & Dry & Fresh & Dry \\
\hline \multirow{3}{*}{$\begin{array}{l}\text { Waste- } \\
\text { water }\end{array}$} & Control & 14.35 & 3.142 & 10.73 & 2.722 & 25.083 & 5.864 & 28.84 & 14.82 \\
\hline & $\begin{array}{l}\text { Recommended Dose } \\
\text { of NPK }\end{array}$ & 18.73 & 3.576 & 11.36 & 2.675 & 30.085 & 6.251 & 39.67 & 15.72 \\
\hline & General Mean & 16.57 & 3.36 & 11.05 & 2.70 & 27.58 & 6.058 & 34.26 & 15.27 \\
\hline \multirow{3}{*}{$\begin{array}{l}\text { Canal } \\
\text { water }\end{array}$} & Control & 12.26 & 2.443 & 9.81 & 2.654 & 22.062 & 5.097 & 28.67 & 12.92 \\
\hline & $\begin{array}{l}\text { Recommended Dose } \\
\text { of NPK }\end{array}$ & 17.69 & 3.274 & 10.93 & 2.725 & 28.620 & 5.999 & 34.47 & 15.25 \\
\hline & General Mean & 14.98 & 2.86 & 10.37 & 2.69 & 25.34 & 5.548 & 31.57 & 13.68 \\
\hline \multirow{3}{*}{$\begin{array}{l}\text { LSD } \\
5 \%\end{array}$} & Irrigation (A) & 0.87 & 0.42 & 0.28 & n.s & 1.52 & 0.42 & 1.56 & 0.28 \\
\hline & Fertilization T.(B) & 3.34 & 0.37 & 0.76 & n.s & 4.23 & 0.53 & 4.32 & 1.16 \\
\hline & Interaction $\mathrm{AxB}$ & 2.15 & 0.45 & 0.46 & n.s & 2.14 & 0.52 & 3.25 & 1.24 \\
\hline
\end{tabular}

Concerning forage quality, data in table 7 indicated that in general, pearl millet had good quality forage, is high in crude protein and its content ranged from 7.5 to 8.9, and digestible nutrients, and low in fiber and lignin. Data also reveal that the differences between water resources recorded significant differences only in crude protein content, soluble carbohydrates and digestibility $\%$. Animal performance did not record any different between the two water resources in forage uptake; this is a better indicator of forage quality.

Regarding to the concentration of heavy metal, data in table 8 , show that the ranges of concentration are within normal ranges. This result is in agreement with the reported results $[19,20]$ and found that available trace elements were positively correlated with fine particles and organic matter content and negatively with free $\mathrm{CaCO}_{3} \%$. They also mentioned that trace elements under 
this condition precipitated in complex compounds and hence its availability was decreased.

Table 7: Effect of irrigation with different water resources, fertilization treatments and their interactions on forage quality of the 2 nd cut of earl millet, grown in calcareous soil. (Average of two year experiments).

\begin{tabular}{|c|c|c|c|c|c|c|c|c|}
\hline Irrigation & $\begin{array}{l}\text { Fertilization } \\
\text { treatment }\end{array}$ & $\begin{array}{l}\text { Crude } \\
\text { protein }\end{array}$ & Fiber & Ash & Fat & $\begin{array}{c}\text { Soluble } \\
\text { carbohydrate }\end{array}$ & \multicolumn{2}{|c|}{ Digestibility \% } \\
\hline \multicolumn{7}{|c|}{$\%$} & 1 st cut & $2^{\text {nd }}$ cut \\
\hline \multirow[b]{2}{*}{ Wastewater } & Control & 7.8 & 30.2 & 10.0 & 10.8 & 49.8 & 62.35 & 53.90 \\
\hline & $\begin{array}{l}\text { Recommended } \\
\text { Dose of NPK }\end{array}$ & 8.9 & 30.6 & 10.2 & 1.9 & 49.8 & 61.64 & 58.85 \\
\hline \multicolumn{2}{|c|}{ General Mean } & 8.4 & 30.4 & 10.1 & 1.9 & 49.8 & 61.90 & 56.38 \\
\hline \multirow[b]{2}{*}{ Canal water } & Control & 7.5 & 31.2 & 10.2 & 1.7 & 49.7 & 60.42 & 54.60 \\
\hline & $\begin{array}{l}\text { Recommended } \\
\text { Dose of NPK }\end{array}$ & 8.3 & 30.6 & 10.1 & 1.8 & 52.1 & 60.25 & 55.29 \\
\hline \multicolumn{2}{|c|}{ General Mean } & 7.9 & 30.9 & 10.2 & 1.8 & 50.8 & 60.34 & 54.95 \\
\hline \multicolumn{2}{|c|}{ LSD for Irrigation (A) } & 0.34 & n.s & n.s & n.s & 0.52 & 0.58 & 0.47 \\
\hline \multicolumn{2}{|c|}{ Fertilization T.(B) } & 0.45 & n.s & n.s & n.s & 0.84 & 0.34 & 0.88 \\
\hline \multicolumn{2}{|c|}{ Interaction $\mathrm{AxB}$} & 0.33 & n.s & n.s & n.s & 0.43 & 0.28 & 0.67 \\
\hline
\end{tabular}

Table 8: $\quad$ Mean concentration of heavy metals in pearl millet plants grown under calcareous soil and irrigated with treated wastewater (Average of three seasons).

\begin{tabular}{|l|c|c|c|c|c|c|}
\hline Irrigation water & $\mathrm{Zn}$ & $\mathrm{Cu}$ & $\mathrm{Cr}$ & $\mathrm{Cd}$ & $\mathrm{Pb}$ & $\mathrm{Ni}$ \\
\hline Wastewater & 31.7 & 3.85 & 0.26 & 0.024 & 0.68 & 0.25 \\
\hline Canal water & 29.8 & 3.22 & 0.14 & 0.020 & 0.38 & 0.16 \\
\hline
\end{tabular}

\section{References}

[1] Abu-Zaid, A.M., Towards an Effective Management of Water Demand in Arid and Semi- Arid Areas: Egyptian Vision. 2nd International Conf. on Water Resources and Arid Environment, Riyadh - Kingdom of Saudi Arabia, 26-29 November, 2006.

[2] Liang, C., Das K.C. \& McClendon, R.W., The influence of temperature and moisture contents regimes on the aerobic microbial activity of a biosolids composting blend, Bioresource and Technology 86. 131-137, 2003

[3] Sudha Bansal, K.K and Kapoor, A. (2000): Vermicomposting of crop residues and cattle dung with Eisenia foetida, Bioresource and Technology 73: 95-98.

[4] Rowe, D.R. \& Abdel-Magid, I.M., Handbook of Wastewater Reclamation and Reuse. Lewis Pub., US., 1995

[5] WRc, Effluent reuse demonstration trials. Alexandria Effluent and Reuse Study, WRc Report No. AESRS 15, 2001

[6] Oron, G., DeMalach Y., Hoffman Z., \& Manor Y. Effluent reuse by trickle irrigation. Water Science and Technology. 24, 9, 103-108, 1991. 
[7] Oron, G., DeMalach, Y. Hoffman, Z. \& Manor Y., Effect of effluent quality and application method on agriculture productivity and environment of control. Water Science and Technology 2(7-8), 1993-1601, 1992.

[8] Shatanawi, M. \& Fayyad, M., Effect of Khirbet As-Samra treated effluent on the quality of irrigation water in central Jordan valley. Water Research 30(12), 2915-2920, 1960.

[9] Vasquez-Montiel, O., Horan N. J., Mara, D. D., Angelakis A., \& Asno, T., Management of domestic wastewater for reuse in irrigation. Water Science and Technology 33(10-11), 355-362, 1996.

[10] Aissi, A., Chouker-Allah, Elmomari H., Hamdi A. \& Soudi, B., Impact of irrigation with treated R. wastewater on infiltration, seepage and uptake on growth of melon (Cucumis melo L.). CIHEAN International Conference, Valenzano, Bari, 22-26, 151-170, 1997.

[11] Palacios, N. P. O. Pard A., Del-Nero E., Rodriguez F., \& Sulos, L., Legumes for Mediterranean forage crops, pastures and alternative uses. Proceeding of the 10th meeting of the Mediterranean sub-network of the FAO-CHIEAM Inter-regional Cooperative Res. Cahiers Options Mediters. 45: 181-185, 2000.

[12] WHO, Health guidelines for the use of wastewater in agriculture and aquaculture. Technical Report No.778. WHO. Geneva p 74, 1989

[13] A.O.A.C, Official Methods of Analysis, 12th ed., Association of Official Agriculture Chemists, Washington D.C. 1984.

[14] Nakayama, F.S., Water analysis and treatment techniques to control emitter plugging. Proc. Irrigation Association Conference,21-24 February, Portland, Oregon, 1982

[15] Gomez, K.A.\& Gomez., A., Statistical Procedure for Agricultural Research-Hand book John Wiley \& Sons, New York, 1984

[16] American Public Health Association, Standard Methods for Examination of Water and Wastewater, 18th ed, AWWA, WPCF, NY, Washington, 1992.

[17] Vyas, A, K. \& Rai, R. K. Response of maize, sorghum and pearl millet as forage to varying levels of macronutrients. Indian Journal of Agronomy 30, 527-528, 1985.

[18] Singh, B. R. \& Singh, D. P., Agronomic and physiological response of sorghum, maize and pearl millet to irrigations . Field Crop Research 42, 57-67, 1995.

[19] Paul, P. K., Sarker D.K., Prasad J. \& Ali M.H., Micronutrients status of alluvial and reddish brown sandy loam soils of Uttar Bradesh. Proceeding of the workshop on Micronutrients, 22 - 23 January 1992, Bhubaneswer, India 103-104, 1993.

[20] Tsakelidou, K., Karagiannidis N. \& Bladenopoulou S., Effect of calcium carbonate and organic matter on soil aluminum, manganese, iron, zinc and copper and their concentration in corn plants in Greek acid soils. Agrochemica 43 (2) 89-100, 1999. 